MATEC Web of Conferences 10, 04002 (2014)

DOI: $10.1051 /$ matecconf/ 20141004002

(C) Owned by the authors, published by EDP Sciences, 2014

\title{
The State of Skilled Components Installers for Industrialized Building System (IBS) Construction in Malaysia
}

\author{
N.R. Buyung ${ }^{1}$, A.N. Abdul Ghani ${ }^{2, a}$ \\ ${ }^{1,2}$ School of Housing, Building and Planning, Universiti Sains Malaysia, 11800, Penang, Malaysia
}

\begin{abstract}
In an IBS construction, the role of the contractor is shifted from a builder to an assembler on the site. Therefore, this requires the contractor to be prepared technologically with IBS knowledge and skills. Unfortunately, the number of skilled IBS installers in Malaysia is still low even though the system has been implemented for a long time. This research is carried out to find out whether the existing number of IBS installers matches existing needs. Primary data has been collected through interviews with construction workers at an IBS construction site in Penang Island in order to get the contractor's feedback regarding this issue. Meanwhile, secondary data has been collected from government agencies to establish the number of existing IBS installers and the number of IBS projects within government projects. The results from this study indicate that not all types of IBS's skill sectors have a shortage of skilled workers. However, there is a critical shortage of precast concrete installers.
\end{abstract}

\section{Introduction}

The Malaysian construction sector contributed $4.6 \%$ of the Gross Domestic Product (GDP) in 2011 with a total value of RM21,370 million for that year. This shows an increase of $24.62 \%$ from 2005, which amounted to RM16,107 million [1]. In 2012, the construction sector contributed $15.5 \%$ of the GDP consisting of $22.2 \%$ in the second quarter and $18.3 \%$ in the third quarter. In enhancing the national revenue, the construction sector was the largest contributor of GDP for the third quarter of 2012 [2]

The importance of the construction industry can be seen from the numerous mega-projects such as Kuala Lumpur Convention Centre (KLCC), Kuala Lumpur International Airport (KLIA) and Government Administration Centre in Putrajaya that have been successfully implemented. Construction activities and other related activities are expected to increase and this will increase the importance of the contribution of the construction industry in the economy [3]. In the face of an increasingly challenging era of globalization, skills and new equipment have been introduced, which includes a system known as Industrialized Building System [4]. This system, introduced by the Construction Industry Development Board in collaboration with the government is now well established. Industrialized Building System is a construction technique in which the components are manufactured in a controlled environment (on or off site), transported, positioned and assembled into a structure with minimal additional site works [5]

\footnotetext{
${ }^{\text {a }}$ Corresponding author: anaser@usm.my
} 
Application of IBS in Malaysia is divided into five types, namely precast concrete system, formwork system, steel frame system, timber frame system, blocks system and other innovative systems [6]. The use of these types of systems has had a positive impact on the construction industry. The advantages of using IBS are: reduction of waste material, reduction of labour on construction sites, reduction of construction materials at site, better quality control, cleaner site conditions and more organized and faster construction times as well as promoting a clean and safe environment [7].

\section{Methodology}

Quantitative research has been used in this research. Statistics from IBS installers and IBS projects have been used in the analysis. Survey research has also being used to get more information for this research. A survey was conducted at an IBS construction site in Penang Island to get the contractor's feedback regarding the IBS installer issue.

Data collection for this research is divided into primary data and secondary data. In this research, the primary data are collected by conducting interviews with construction workers such as the project manager, site supervisor, resident engineer and others at the IBS construction site in Penang Island. The interview was conducted to get the contractor's feedback regarding the IBS installer or skilled workers issues. These interviews were also conducted to achieve the second objective of the research. They are also to strengthen the assumption or hypothesis, which has been made on the issue of IBS skilled workers or installers. In addition, an interview with the IBS Centre officer was also conducted to get other information relevant to this research.

Meanwhile, secondary data was collected from government agencies, which are from CIDB, ICU PMD and ABM. This secondary data was taken to achieve the first objective of this research that is to determine the current status of IBS skilled workers or installers in Malaysia according to the skill required and the number of IBS projects in Malaysia. In this case, the data for the number of IBS projects in Malaysia was taken from the ICU PMD from the year 2010 until year 2012. Meanwhile the number of IBS installers is taken from IBS Centre, which is the total number from each ABM in Malaysia

\section{Results and Discussion}

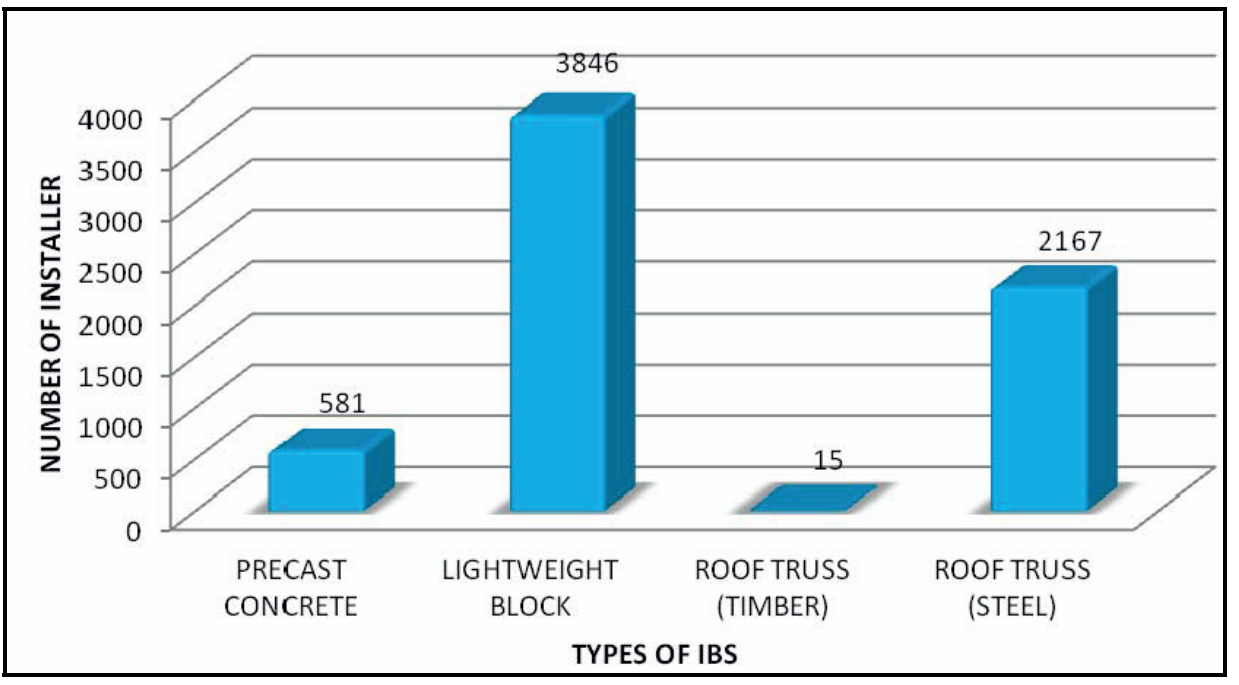

Figure 1. Registered IBS installers up to 2011

The overall total number of registered installers is 6609 people. The total number of lightweight block installers shows the highest number compared to other IBS types with a total of 3846 people 
from 2009 until 2011. This is followed by steel roof truss installers, with 2167 people. However, there are large differences between the number of precast concrete installers and the lightweight block and steel roof truss installers. The timber roof truss shows the lowest number of installers compared to the others.

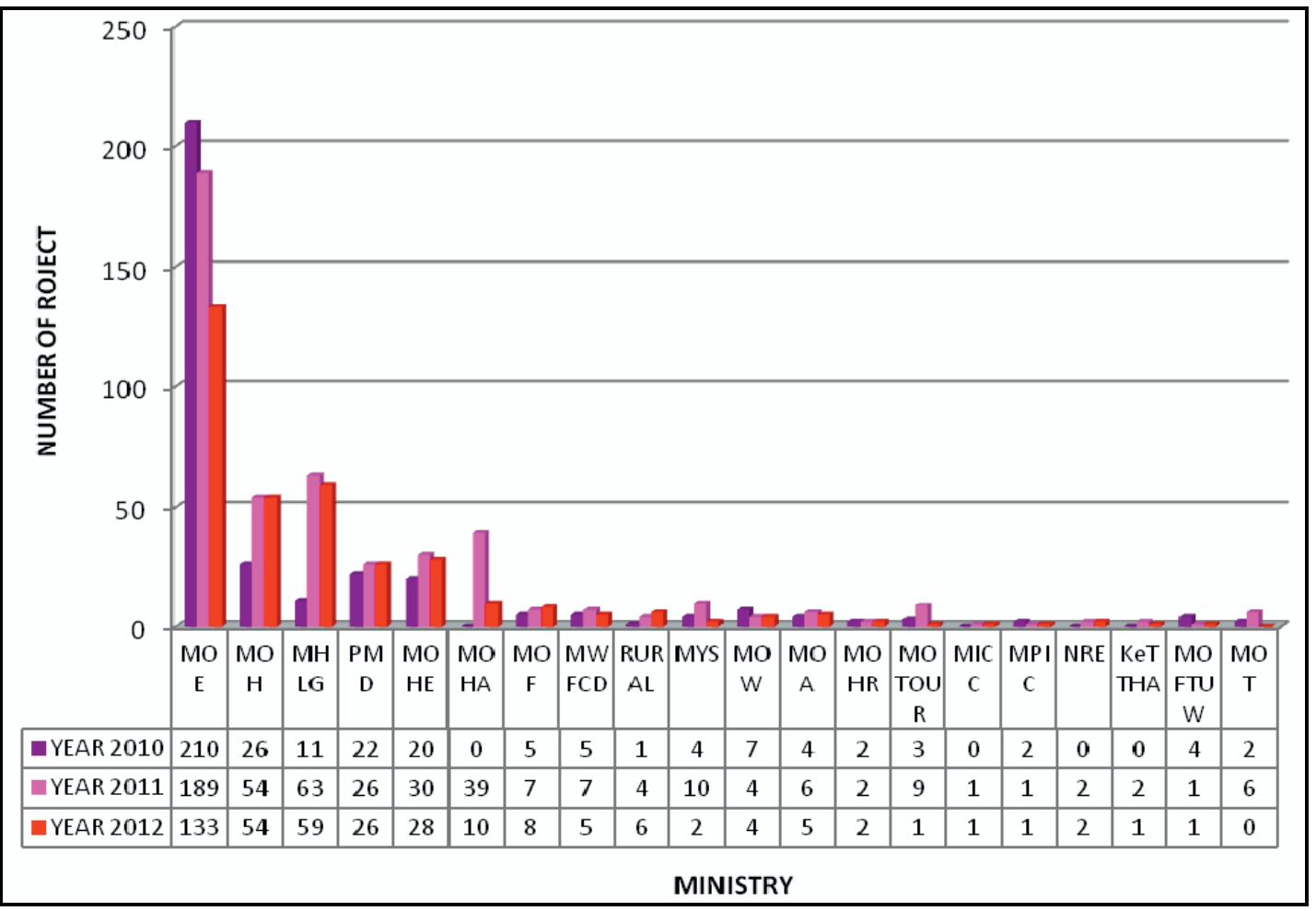

Figure 2. Project distribution based on ministry

As shown in Figure 2, it can be seen that there was an increase in the number of projects for 2011 but in 2012, the number of projects slightly decreased. As a whole, almost all ministries had a decline 2012. The ministry with the largest number of projects among the ministries is the Ministry of Education. There are only 5 ministries with more than 10 projects. Another 14 ministries have less than 10 projects. Significant differences can be seen between the number of project by the MoE and the other ministries.

As shown in Figure 3, it can be concluded that almost all states show an increasing pattern from 2010 until 2011. While in 2011, the number of projects in all states decreased. The state with the largest number of projects in Malaysia is Selangor with a total number of 274 projects from 2010 until 2012. Selangor is followed by Johor with a total of 165 projects for three years. Significant differences can be seen between the number of projects between Selangor and other states.

The state with the lowest number of project is Perlis with a total of 16 projects. There are a few states with a total of less than 50 projects which are Melaka with 26 projects, Terengganu with 33 projects, Kelantan with 34 projects, Sarawak with 38 projects and Penang with 40 projects.

One factor affecting the number of projects in the Malaysia Plan is the provision for every ministry given in the Malaysia Plan. For 2010 the provision was under the Ninth Malaysia Plan while 2011 and 2012 are under the Tenth Malaysia Plan. Every ministry is given its provision and based on the provision given by the government, all the ministries are divided based on their requirements. If they have a plan for a construction requirement such as building an office or school, the provision will be distributed according to the states. 


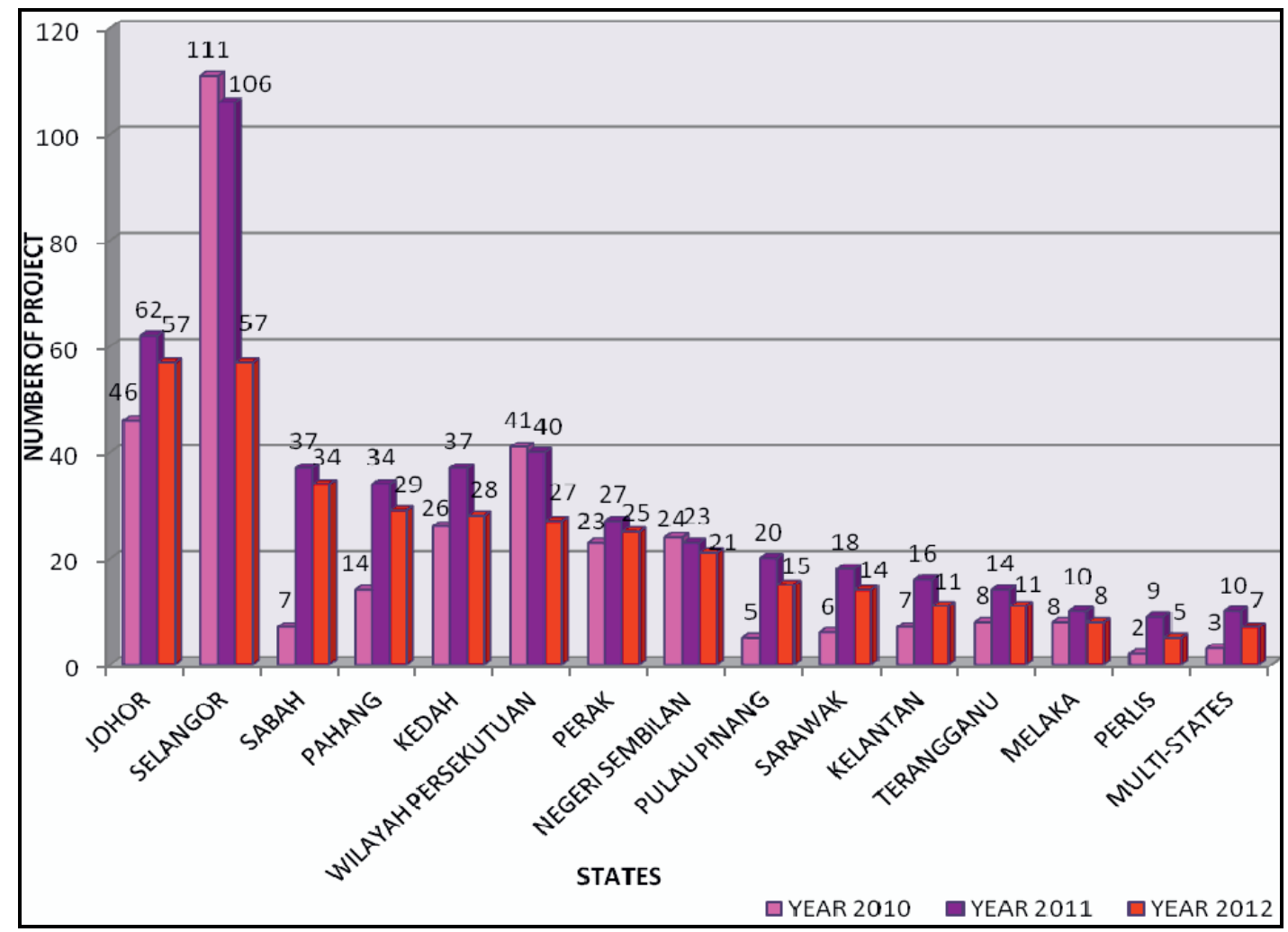

Figure 3. Project distribution based on states

In this study, the types of precast concrete projects that are experiencing a shortage of skilled installers are both current projects and future projects. The increase in the number of projects, if not followed by an increase in installers, will cause a higher demand for precast installers as it is difficult to get a skilled precast installer. This can be proved by the precast concrete installer shortage in Case Study 1. In addition, the number of skilled precast installers is lower compared to the number of skilled lightweight block installers and steel roof truss installers.

In fact, timber roof truss installers are also experiencing a shortage of skilled installers in either the current projects or the overall projects. Among the four types of installer, the number of timber roof truss installers is the lowest compared to other IBS installer types. However, steel roof truss installers are also deficient for the overall projects if the number of installers is not considered.

It can be seen that there is an excess of lightweight block installers. The total of existing installers is able to meet the needs of current and future projects. However, in the interviews with the IBS Centre officers, they said that installation of lightweight block can be done without using skilled lightweight block installers. Therefore, the contractors can use general workers for lightweight block installation. The contractors tend to use general workers or use less skilled installers to reduce costs, as the wages of general workers are less than skilled workers.

\subsection{Case study 1 - School project}

Project name: "Cadangan Membina dan Menyiapkan Sebuah Projek IBS yang Mengandungi 10 Buah Bilik Darjah dan Kemudahan Berkaitan bagi Sekolah Kebangsaan Minden Height, di atas Lot 3432, Bandar Gelugor, Daerah Timur Laut, Pulau Pinang”

Project owner: Ministry of Education (MoE)

Main contractor: Azrul Enterprise Sdn. Bhd 
This project consists of one four-storey building which is for administration and academic use (Block A) and one two-storey building for science laboratories (Block B). This project used IBS methods in terms of precast concrete. They used two IBS component specialists from Creative Precast Technics Sdn. Bhd. for beams, half slabs and stairs and Acotec Wall Panel for wall panels. From the interviews, this project was experiencing a shortage of installers. The problem occurs when there is a project nearby using the same IBS specialists. When the project nearby was facing a delay in their construction, the same IBS specialists took a few skilled installers from this project to do critical works on that project. This has caused a shortage of skilled installers for this site and the installation works were delayed.

\subsection{Case study 2 - School project}

Project name: "Cadangan Meroboh, Pindahan dan Tambahan (IBS) kepada Bangunan Sekolah Sediada Sekolah Kebangsaan Sungai Gelugor (30 BD) di atas Lot 3356, 3357, 3362, 3389, 3390 dan 3446, Mukim 13, Bandar Gelugor, Pulau Pinang"

Project owner: Ministry of Education (MoE)

Main contractor: Paticorp Sdn. Bhd

The development project is for amendments and additions to building works for classrooms and administration offices of a four-floor building (Block A), amendments to a four-storey academic block (Block B) and a bus stop barrier or wall, the amendment or addition to a one-storey kindergarten block (Block D) and refurbishment of a block of two-storey buildings to Sekolah Kebangsaan Sungai Gelugor, Pulau Pinang. It can be summarized that the project consists of development and amendments works for four school blocks.

This project used IBS types of precast concrete. They used two IBS component specialists from Creative Precast Technics Sdn. Bhd. for beams, half slabs and stairs and Acotec Wall Panel for wall panels. These are the same specialists from Case Study 1.

From the interviews, this project had never experienced a shortage of installers. No problems occurred during the construction even though there was a project nearby using the same IBS specialists. However, they experienced a delay in their project and needed to use two teams of installers and had to rent another crane in order to cover a delay.

\section{Conclusions}

The results from this study have shown that the number of precast concrete installers is encountering a critical shortage of installers. This is because the total number of existing installers can only accommodate a small number of projects, which is 166 projects or $18 \%$ of the total projects. In addition, there is also shortage of timber roof truss installers but these can be replaced by the steel roof truss installers because the number of steel roof truss installers is sufficient. There are more than enough lightweight block installers. In conclusion, there will be a high demand for precast concrete installers. Hence, the parties responsible for the supply of precast concrete installers should play a role in compensating the precast concrete installer shortage. To get a better quality of installation, they need to use skilled installers and by using skilled precast installers, undesirable outcomes can be avoided such as mistakes in assembling components, jointing and others.

\section{References}

1. CIDB Malaysia, IBS Digest January - March 2005, CIDB Malaysia, 2005, pp: 4-8

2. W.A.M, Thanoon, L.W. Peng, M.R. Abdul Kadir, M.S. Jaafar, M.S Salit, The Experiences of Malaysia and Other Countries in Industrialized Building System in Malaysia, Proceeding on IBS Seminar. UPM, Malaysia, 2003. 
3. CIDB, Construction Industry Master Plan (CIMP 2006-2015). Construction Industry Development Board Malaysia (CIDB). Kuala Lumpur, 2007.

4. M.R. Abdul Kadir, W.P. Lee, M.S. Jaafar, S.M. Sapuan and A.A.A. Ali, Factors Affecting Construction Labour Productivity for Malaysian Residential Projects, Journal of Structural Survey. 23 (1) (2005) 42-54

5. N.Y. Maamor, Safety Aspect in Installation Industrialized Building System (IBS) Component, 3. Research Study for Bachelor Degree in Civil Engineering, UMP, 2007, pp: 65-69

6. Y.F. Badir, M.R. Abdul Kadir, A.H. Hashim, Industrialized Building Systems Construction in Malaysia , Journal of Architectural Engineering, 8 (1) (2002) 19-23

7. M.R. Abdul Kadir, W.P. Lee, M.S. Jaafar, S.M. Siouan and A.A.A. Ali, Factors Affecting Construction Labour Productivity for Malaysian Residential Projects, Journal of Structural Survey. 23 (1) (2005) 42-54 